\title{
Lidil
}

Revue de linguistique et de didactique des langues

$52 \mid 2015$

Les pratiques artistiques dans l'apprentissage des langues

\section{Using Drama Activities in an Oral Expression Class for Trainee English Language Teachers in a French University Setting (MEEF 1)}

Utiliser des activités théâtrales dans un cours d'expression orale pour les

étudiants de MEEF 1

Mark Gray

\section{CpenEdition}

\section{Journals}

Electronic version

URL: http://journals.openedition.org/lidil/3839

DOI: 10.4000/lidil.3839

ISSN: 1960-6052

\section{Publisher}

UGA Éditions/Université Grenoble Alpes

\section{Printed version}

Date of publication: 20 November 2015

Number of pages: $83-106$

ISBN: 978-2-84310-312-4

ISSN: $1146-6480$

\section{Electronic reference}

Mark Gray, « Using Drama Activities in an Oral Expression Class for Trainee English Language

Teachers in a French University Setting (MEEF 1) », Lidil [Online], 52 | 2015, Online since 01 January

2017, connection on 30 October 2020. URL : http://journals.openedition.org/lidil/3839 ; DOI : https:// doi.org/10.4000/lidil.3839

(C) Lidil 


\title{
Using Drama Activities in an Oral Expression Class for Trainee English Language Teachers in a French University Setting (MEEF 1)
}

\author{
Mark Gray*
}

\begin{abstract}
This article describes in some detail the drama-based approach and activities used in an oral expression class taught by the author as part of the first semester of the Masters (MEEF 1) program at the Université Paris Est-Créteil. Based on the author's reflective analysis of his own classroom practice, the article seeks to show how certain aspects of drama training can be applied to address the specific performance demands of the oral exam of the CAPES (Certificat d'aptitude au professorat de l'enseignement du second degré). It is argued that such a drama-based approach is particularly suitable for training students in order that they might better meet the jury's non-language requirements for these épreuves orales.
\end{abstract}

\section{RÉSUMÉ}

Dans cet article, l'auteur propose une description détaillée des activités théâtrales utilisées dans un cours d'expression orale avec des étudiants de MEEF 1 à l'université Paris Est-Créteil. Basé sur l'analyse réflexive de la pratique pédagogique de l'auteur, l'article cherche à montrer de quelle manière certains aspects de la formation des comédiens pourraient être mis à profit pour préparer les futurs candidats au CAPES à faire face aux impératifs non linguistiques (c'est-à-dire physiques et psychologiques) des épreuves orales du concours.

* Université Paris Est-Créteil, IMAGER EA 3958. 


\section{Introduction}

The use of drama in language teaching is not a new phenomenon. Practitioners have been outlining its potential benefits for at least forty yearsbeginning perhaps with the publication of Via's English in Three Acts (1976) and the first edition of Maley and Duff's Drama Techniques in Language Learning (1978). Among the potential benefits that have been identified are improved motivation (Stern, 1980; Maley \& Duff, 2005; Dicks \& Le Blanc, 2009), a higher degree of empathy (Aden, 2003; DiNapoli, 2003, 2009) and greater self-esteem for the learner (Stern, 1980; Wessels, 1987; Fung, 2005).There is still great interest in drama in the language classroom. Recently published materials include the third edition of Maley and Duff's Drama Techniques (2005) and Ken Wilson's Drama and Improvisation (2008). More specifically, drama practice at university level is also attracting more interest, as witnessed by recent work by Agarra and DiNapoli (2012), and Cornaz and Fonio (2014). And yet from informal reports from students enrolled on the first year of the MEEF programme at the Université Paris EstCréteil it would seem that overtly drama-based approaches are actually used rather sparingly. Indeed, most students on the oral English course which will be described in this article report that they have had little or no previous exposure to the type of drama activities they encounter during the course.

One possible explanation for this might be drama's reputation for being not much more than a set of rather frivolous games which may be used to fill in time when the real work of the class has been done, and better suited to younger learners in any case. Via (1981) identified this as one of the greatest barriers to the implementation of a dramabased approach and attributed the negative attitude of many language teaching professionals towards it to a misunderstanding of what drama actually is:

People in the world of TESOL must come to realize that drama, once it is clearly understood, is not Mickey Mouse. It can be fun and should be but it is at the same time deserving of recognition as a serious and theoretically sound pedagogical construct. (Via, 1981, p. 211)

As I hope to show in this article, my experience in the university classroom would seem to lend support to Via's claim that when taken seriously drama can be an extremely effective tool.

Although I will take a resolutely positive view of the use of drama techniques at university level, potential barriers to implementing a 
drama-based approach will also be discussed. These barriers include possible resistance from students to the use of drama, a certain degree of fear on the part of teachers (Royka, 2002) as well as issues surrounding evaluation. In addition, the question of what "level" of drama training is required for any teacher wishing to implement such an approach in their class will be considered.

In the next section of the article, I will outline what I consider to be the main characteristics of the specific performance demands of exams such as the CAPES orals, I will then set out to demonstrate how implementing a carefully tailored drama-based approach might be particularly appropriate for training students to better meet these demands. For that purpose, I will describe in some detail the drama-based approach and specific activities I have used in an oral expression class which forms part of the first semester of the Masters (MEEF 1) program at the Université Paris Est-Créteil. The article will be based largely on a reflective analysis of my own classroom practice, and will also include a brief qualitative analysis of the students' experience of the class.

\section{Performance demands of the CAPES oral exam (épreuves orales)}

The performance demands of the CAPES oral exam may be analysed in terms of the action-oriented approach adopted by the CEFR (2011). Within this approach, language users and language learners are viewed primarily as:

[...] members of society who have tasks (not exclusively languagerelated) to accomplish in a given set of circumstances, in a specific environment and within a particular field of action. (CEFR, 2011, p. 18)

The tasks of the CAPES oral exam are two-fold. First, candidates have to make a formal 20-minute presentation to a small expert audience (the jury) on aspects of Anglophone culture and society on the basis of a set of short documents provided to the candidate beforehand. Second, they have to interact with the jury in a question and answer session after the presentation has been made.

The combination of the specific nature of these tasks and the circumstances and environment in which they must be accomplished poses a considerable challenge to candidates. It should be noted that the oral exam represents the final stage in the CAPES selection procedure and that only those candidates who pass the written exams (épreuves écrites 
d'admissibilité) are able to go through to the oral stage. Based on the figures published online by the French Ministry of Education (Ministère de l'Éducation nationale, 2012a, 2013a, 2014a) the percentage of candidates admitted to the oral stage of the CAPES in the last three years was just over 60 percent. Among those candidates who were eligible to take the oral exams, the average success rate during the same period was slightly more than 56 percent. For many students the CAPES oral will be the first time they have had direct experience of such a formal interview situation. Moreover, as the CAPES is a competitive national recruitment exam (concours de recrutement), the orals are organised nationally and take place in a single location. As a result, many candidates may have to travel to an unfamiliar city - perhaps several hundred kilometres from their home-and this can represent an additional challenge.

Clearly then, while the language demands on the candidates may be obvious (they must know the programme, master the grammar, vocabulary and pronunciation of English to an acceptable level, etc.), students should not neglect the "non-language" aspects of the task at hand. In each of its annual reports on recent sessions of the CAPES, the jury reminds candidates of certain aspects of communicative performance on which they will be judged (Ministère de l'Éducation nationale, 2012b, pp. 63-4; 2013b, p. 71; 2014b, pp. 77-8). For the purposes of this article, I propose the following summary of the jury's expectations:

(a) Formal linguistic factors (oralité du discours).

Candidates need to demonstrate awareness and a command of the differences between written and oral communication. The Rapports de jury specifically highlight the need for candidates to be able to speak from a plan and notes rather than simply reading a prepared speech out loud. The reports make it clear that candidates are required to engage with the jury via appropriate body language and eye contact during the exam. At the same time, candidates are also reminded that they are required to adopt an appropriately formal language register and are warned against the use of informal discourse markers such as you know, you know what I mean, etc.

(b) Factors related specifically to the use of the voice (niveau sonore et débit).

The Rapport emphasises the importance of clear, well articulated speech and warns candidates against speaking too slowly or too quickly and of speaking too loudly or too softly. 
(c) Extra-linguistic factors (attitude générale).

Finally, the Rapport refers to the importance of the candidates' general physical attitude and behaviour in the exam room, and warns them against allowing the stress of the situation to lead them to behave in an aggressive of agitated manner.

Over and above the language requirements of the exam, the jury recognises that the CAPES oral exam can be particularly stressful-not least because many candidates often have to travel and to stay overnight in an unfamiliar town in order to take it, aware that their future career depends on whether or not they are successful in the exam. In the report on the 2013 session of the CAPES externe candidates are specifically reminded of the need to prepare for the physical and psychological demands of the oral exam.

\section{Identifying relevant drama activities to prepare for the CAPES oral exams}

It is important to identify the specific type of drama activities that may be used to train students to become better "performers", in the sense outlined above. The influence of the communicative language teaching approach over the past three decades means that - in Europe at leastmost students of a foreign language are likely to have encountered some form of drama-based activity at some point during their languagelearning career. Beaven and Alvarez (2014) characterise what is often meant by "drama-based" in this context:

Common examples of what has been understood as drama-based teaching $[\ldots]$ are the role-plays, simulations and retelling of stories of different kinds into which every language learner is almost inevitably initiated from the very first stages of their learning process. These are mostly set as communicative tasks that aim at facilitating realistic interaction in secondary, and to a lesser extent in primary or tertiary education. (Beaven \& Alvarez, 2014, pp. 5-6)

While activities such as role-plays and simulations undoubtedly can provide an opportunity for students to practice their oral skills in the foreign language, it is highly questionable whether the simple fact of their being used in the classroom equates to "drama-based teaching". DiNapoli (2009) observes that students often do not fully engage with role-play or pair-work activities when these seem to focus exclusively on practicing specific language forms and functions. 
The introduction of role-playing as a methodology in university L2 learning courses in recent years has done little to alter this pattern. To some extent, this stems from the fact that textbooks frequently provide functionally rhetorical dialogues and information focused role-play tasks, which rarely take human sentiment into consideration. [...]

The shortcoming of this sort of activity is that students focus on repository facts and strategic functions, without addressing the potential meaning that arises from sentiment. Attending exclusively to the lexical, grammatical, functional and strategic aspects of language substantially reduces the performers' communicative options. (DiNapoli, 2009, p. 100)

The type of shortcomings that DiNapoli refers to here were already being flagged up over thirty years ago by Via, who insisted that, rather than the product, it was the process of doing drama that was important:

[...] it is the process of working on a play that is important, not the final production. And by process I mean the use of suitable drama techniques in working with the students. [...] Drama technique includes such activities as mime, improvisation, observation, relaxation, and the use of the entire body. These activities, which are all intimately involved with drama, can be an integral part of most language classrooms. They may take up five minutes of class time or the entire class period depending on the needs of the group, or the goals of the teacher. Education is concerned with the individual, whereas drama is concerned with the development and nurturing of the individuality of the individual. Thus, we put drama in proper perspective. It is not a panacea, but it can be powerful medicine. (Via, 1981, p. 211)

The link between drama in the language class and acting trainingwhere scene-work is only one part of the overall programme of studybecomes apparent here; it is something which is recognised by Maley and Duff who state that the activities they describe in their resource book are "based on techniques used by actors in their training" (Maley \& Duff, 2005, p. 2). This article will therefore focus on this broader conception of "drama technique". I will seek to show how certain aspects of professional drama practice (i.e. aspects of the professional practice of teachers of drama and acting, as well as by directors) can be beneficial to students preparing for the CAPES oral exam.

Cusset (2013) has outlined the parallels which should be drawn between the theatre and the role of the teacher (whatever the subject taught), and similar parallels exist between a candidate's role in the CAPES oral exam and an actor's role in a stage play. In both cases, 
there is a "performer" (the CAPES candidate, the actor) and an "audience" (the CAPES jury, the theatre audience). Of course, the jury in the CAPES is a very particular kind of audience, and may also be considered to be "part of the play" in that its members interact directly with the candidate. Nevertheless, in an exam situation such as this, it is very much the performance of the candidate which is under observation by the jury. As in the theatre, the "performer" needs to be seen, to be heard and to be convincing in their portrayal of their allocated role. Certain skill-sets need to be developed in order to deliver a convincing performance in both cases, and those skill-sets can only be developed through practice.

Bearing this in mind, I propose the following list of common competencies. While not purporting to be definitive or complete, this constitutes a useful starting point for the task of identifying the types of drama activity that might be particularly useful for CAPES candidates. Both trainee actors and CAPES candidates need to do the following:

(a) Accept the fact of being observed by an audience without becoming overly self-conscious.

(b) Be aware of their body language and of the impact it can have on the audience.

(c) Be aware of their voice and how it is affecting the audience.

(d) Be able to control their speech rate.

(e) Be aware when they have the audience's attention, and when they do not.

In addition to the above, as indicated in the Rapports de jury, CAPES candidates also need to be able to speak spontaneously to the examiners (Ministère de l'Éducation nationale, 2012b, p. 63; 2013b, p. 71; $2014 b$, p. 77). This demand is to some degree similar to that made of an improvising actor who may have to give an improvised monologue to a theatre audience.

There are a number of aspects of drama training that can enable students to practice the performance skills they will need both on the day of the CAPES oral exam and in their future teaching careers (see Cusset, 2013). More specifically, I will endeavour to show how drama training can be of use in helping students to practice and improve performance in each of the following areas:

(a) Body language and eye contact. 
(b) Voice production - articulation, speed of delivery, voice projection.

(c) Speaking spontaneously.

\section{Outline of the course and class make-up}

\subsection{Overview}

At the Université Paris Est-Créteil, the oral English class which takes place in the first semester of the first year of the Master Métiers de l'enseignement, de l'éducation et de la formation (MEEF 1) consists of thirteen weekly two-hour sessions. The oral expression class is not a drama class per se; drama techniques are used in order to help students become more proficient and confident public speakers in English. Particular focus is placed on developing self-awareness and self-confidence. The more strictly linguistic competencies required in the CAPES examsuch as pronunciation, grammar and vocabulary - are dealt with as and when they arise, but the course content is essentially geared towards the development of performance and public speaking skills.

During the first session of the course, students are given a handout on which the following course description is provided:

\section{Overview of course objectives}

This course aims to provide students with a practical and theoretical training relevant to becoming a proficient and confident public speaker in English. This is a vital skill. As teachers we have to stand up and talk in public almost every day of our working lives, so we might as well learn to enjoy it!

The oral exam of the CAPES requires candidates to speak in front of jury for around 30 minutes. Candidates need to show the jury that they are confident and competent speakers of English, capable of providing an acceptable model of English pronunciation in the classroom.

In addition to some theoretical sessions, this course will be highly practical. We will be doing a wide variety of exercises designed to help you become more proficient and confident when speaking in public. Some of the exercises will require a certain amount of bravery on your part. But remember that for almost all of us, improved performance in public speaking means practice, practice and more practice!

Active participation and commitment is expected from all students who attend this class. (Extract from the handout given to students enrolled on the MEEF 1 oral English class at UPEC.) 
The grades awarded to students who attend the class are based on active participation in class (50 percent) and on a prepared presentation that must be given in front of the rest of the group (50 percent). It is made clear to students from the outset that active participation and commitment is required in class activities and that the evaluation will be geared to this aspect of the training just as much as to the more traditionally identified factors such as pronunciation, grammar and vocabulary. The rationale behind this is to encourage all the students on the course to regard oral communication as something they can and will get better at through regular practice.

\subsection{The students}

The course described here was developed over a period of three years. Over the three years, a total of 47 students attended regularly, an average of around 17 students per year. There was a clear gender imbalance, with female students outnumbering male students by a ratio of approximately three to one. The average age of students was around 23 but in each year there were one or two older students aged over 30, 40 or even 50. Approximately 60 percent of the students attending the class had spent a prolonged period of 6 months or more in an English-speaking country (usually the United Kingdom or the Republic of Ireland).

\section{Description of the drama activities used in the class}

It was important from the outset to create an atmosphere conducive to this type of work, and to make it clear to the students exactly what was expected from them in terms of participation. In this section, I will therefore describe in some detail a typical first session of the MEEF 1 oral English course.

\subsection{Setting the parameters: a typical first session}

\subsubsection{Arranging the space}

Classrooms at the university are not usually designed with drama work in mind, and one practical consideration that needs to be taken into account is the space. For drama work to be effective, for there to be action, it is necessary for the students to be able to move around the space. Concretely, this means requesting from the institution a large room in which, if possible, the furniture can be moved. To foster a participatory atmosphere in group, it is important that the students be made 
responsible for setting up the space at the beginning and end of each session. This sets the routine to be followed in future weeks and very quickly the students come arrange the furniture at beginning and end of each session without being prompted to do so.

\subsubsection{Name-learning game}

As was noted in section 2, the CAPES jury expects candidates to use appropriate body language and to make eye contact during the exam. This first exercise is designed to begin work on these aspects of public performance and to foster a positive group dynamic. The activity is based on the game And I'm a butcher described by Maley and Duff (2005, p. 30).

With everybody standing in a circle (including the teacher), I demonstrate the activity by introducing myself to the group with the simple sentence: "My name is Mark." As I speak the words, I perform the action of introducing myself-I make eye contact with the rest of the group and gesture towards myself with my hand. I then invite the student standing on my right (let's say her name is Julie) to introduce herself in the same way - "My name is Julie". If necessary, I remind Julie to use the appropriate body language to engage with the group (i.e. eye contact and hand gesture). I then introduce the second stage of the activity, by gesturing towards Julie, saying "Her name is Julie ... and my name is Mark" (again with accompanying gestures). I then invite the student to my left to continue the sequence: "Her name is Julie, his name is Mark, and my name is..." The students will by now have realised the challenge is to memorise the names of all the students (and the teacher!) to their right and those towards the end of the circle may begin to feel a little anxious. It is therefore important to emphasise that it is just a game, and that mistakes and slips of the memory are to be expected. However, it is also important to insist that it is perfectly achievable. Whenever a student cannot remember a name, they can ask the person concerned to remind them. It is important to insist that the students engage with each other through eye contact. The object of the exercise is not simply to remember everyone's name but to establish a way of working. This activity sets the tone of the classes to come. We are focussing on action and interaction just as much as - if not more than - on the simple production of language forms. In this particular exercise it is important for the teacher to also fully engage as a participant. I always make a point of being the last one to try to repeat all the names. If I make a mistake, this also helps relax the students, promotes group bonding and plants the idea that the teacher is not infallible! 
This activity can then be developed in order to reinforce the memorisation of everybody's name and to get students moving in the space. Still standing in a circle, the teacher demonstrates by looking at somebody across the circle to catch their attention, calling them by their name, making eye contact, and then slowly advancing across the circle towards them to take their place. Before I arrive at their place, the student whose name has been called must look around the circle and catch another player's attention, make eye contact, say their name and advance towards them. The third player must then do the same by attracting the attention of a fourth player, and so on. It is important to insist that players make eye contact before setting off across the circle. Players are not allowed to change places with the person next to them in the circle! This game can continue for a few minutes until everyone has moved at least twice.

These introductory activities break with the traditional setting of the classroom, with the students sat in rows facing the teacher at the front of the class. Moreover, by getting the students to stand up, to look at each other and to move around the space some basic requirements of a drama-based approach are set-drama is action.

\subsubsection{The exposure exercise}

Many students complain of feeling anxious at the prospect of having to stand in front of the class. The object of this activity, which is based on an exercise described by Viola Spolin (1999, pp. 53-5), is to give them some tools to help overcome this fear. The exposure exercise provides a very simple and relatively non-threatening way of raising students' awareness of how comfortable they feel in front of an audience, and how focussing on an activity can lessen any performance anxiety they may have. The exercise builds awareness of both how it feels to be exposed and observed by others, and how it feels to observe others in the same predicament. The feedback session afterwards is an important part of the process as students are encouraged to reflect on how they felt as both "performers" and audience members.

The class is divided into two groups. The first group goes to the front of the room with the instruction to just stand there, while the second group sits as an audience. After a minute or two, once most of the "performers" have shown signs of self-consciousness, the first group is asked to carry out a specific task, such as counting all the chairs in the room. Again, the second group forms an audience and just observes the first group. After a minute or two, the groups switch 
roles and the sequence of tasks is repeated. Finally, both groups are brought back together as an audience for a feedback session during which the teacher asks the students to say how they felt during each of the four stages of the exercise, first as "performers" doing nothing, then as performers doing a simple activity, then as "observers" when the "performers" were doing nothing, and finally when the "performers" were doing an activity. While the feedback session will tend to reveal that some students are naturally more comfortable with being observed than others, it is important for the teacher to make it clear that for most people, being observed is not a usual behaviour and is something most of us tend to avoid when we can. However, it is also something that with practice we can get used to and feel more comfortable with.

Students usually find that the addition of the activity in stage two of the exercise makes them feel less uncomfortable. It also helps them to realise that empathy plays an important role in human communication (Aden, 2008), and they express that even as an audience it is particularly difficult to watch somebody who is feeling self-conscious. This work forms a good foundation for future work in class when students have to give presentations, and it can be referred back to whenever the occasion arises. It is also a very practical demonstration of the fact that for the teacher/CAPES candidate there is "no hiding place". They are on show and that is something that must be accepted and, hopefully, embraced!

\subsubsection{Personal anecdotes}

An important performance skill for students to acquire is that of being able to engage an audience. The exercise described below is a variation on the theme of the activity Whose Story is True, described by Johnston (2010, p. 57) and is the sort of activity which is often used in actor training. In addition to working on storytelling skills, it helps develop observation and awareness of body language and give valuable practice in speaking in front of the group.

The group is divided into pairs (Student A and Student B) and each pair is told to find a space in the room to go and sit together where they will not be overheard by the other students in the group. When all the students are in their pairs, the teacher tells every one to think for two minutes about a true story that actually happened to them when they were a teenager. I usually provide an example of an anecdote from my own youth at this point to take any pressure off. I tell them to avoid recalling traumatic or overly embarrassing moments and focus on some- 
thing which they feel comfortable sharing with the others. After a few minutes, I instruct the pairs to exchange anecdotes as follows: Student A tells his or her anecdote to Student B. The anecdote should last for between one and two minutes. Student B just listens. Then A and B swap roles, and Student B tells his or her anecdote to A. Once each pair has shared their anecdotes, I tell them that they should now choose which of the two anecdotes they find more interesting. Once this choice has been made, whichever student told the anecdote must teach it to their partner. The objective is for both partners to be able to tell the anecdote as if it were their own. I usually allow ten minutes for this stage as it is important for both students in the pair to be able to tell the anecdote as if it were their own.

Once the pairs have each learned one anecdote, I bring the class together as an audience and ask for one pair to come to the front of the class. Each member of the pair now tells the anecdote to the rest of the group, with no interruptions or comments. After the two versions of the anecdote have been told, the audience, as a group, are allowed to ask one question to each of the storytellers. Each member of the audience must then say who they think is telling the truth and why. The reasons given often allow the group to reach some conclusions about what sort of body language tends to give the "liar" away. I always encourage the group to applaud the storytellers at the end of their sequence before the next pair come up and take their place. This is important in order to boost confidence and to help establish trust within the group.

The personal anecdote exercise is absorbing for both speakers and audience. It is a relatively low-pressure way of introducing the students to speaking in front of the group. The content of the story is not important, and anyway, they get the chance to share it with just one other person before having to talk in front of the group. As such it is an ideal way to start the semester.

\subsubsection{Hand out the course outline}

It may seem counter-intuitive to leave this stage until the end of the session; however, I believe that it is important to get the students to be active from the outset. Going through the course at the end of the class provides an ideal opportunity to highlight the relevance of the activities the students have done in class up to this point to the objectives of the course. 


\subsubsection{Debriefing and feedback}

It is important to conduct a short debriefing session at the end of the class as it gives the participants a moment to step out of the roles they have been playing in the drama activities and to reflect on their learning. For the debriefing session, I get the students back in the circle and tell them to think for one minute to formulate one phrase about what they will take away from the work done during the session. I then go round the circle and invite students to share their phrase. I tell them that it doesn't need to be a particularly interesting sentence, but that it just needs to be honest. It might be related to the anecdotes, or to how they felt during the exposure exercise. I then end the session by telling the students to read the course outline at home and to look up the Rapport de jury on the internet.

\subsection{Other drama activities used during the semester}

After the parameters of the class have been established in week 1, further drama-based activities are introduced as the semester progresses. Rather than presenting them in chronological order, I will provide a thematic breakdown of those activities of particular relevance to the non-language performance demands of the CAPES described in sections 2 and 3: breathing, voice and articulation; status games; speaking spontaneously.

\subsubsection{Breathing, voice and articulation}

The use of tongue twisters to practice pronunciation of difficult sequences of phonemes is generally well-received by the students, particularly once the drama techniques have been established as part of class procedure. In order to raise the dramatic stakes, I get the group to line up across the room and then ask one student at a time to come to the front to deliver the tongue twister as if it were an important message to be delivered to, say, a group of despotic rulers. The despotic rulers must either accept or reject the message on the basis of how well it is delivered. This game works extremely well and seems to motivate most students rise to the challenge.

As professional voice teachers and coaches are apt to remind us, correct posture and breathing technique are fundamental to good voice production (see, for example, McCallion, 1998). Part of the objective of the MEEF 1 course is to raise students' awareness of this. Therefore, over the course of the semester, I begin each week's class with a few 
basic stretching and vocal warm-up exercises that I have either personally experienced as a participant in workshops at the Actors' Centre, or which are inspired by those described by Maley and Duff (2005, pp. 69-79) and Hardison and Sonchaeng (2005). With exercises of this type, it is important for the teacher to be active along with the students, to show them what to do. A potential obstacle to the use of such exercises is that they may make some people feel uncomfortable or even ridiculous. It is therefore important that any voice session be handled with care. Indeed, most teachers would probably benefit from following a voice workshop themselves before attempting to lead a group in anything other than the most basic of exercises. However, if the teacher is confident and explains how the exercises can help with articulation and pronunciation, most students overcome any initial reticence and participate well. They also tend to be open to phonetic correction when provided.

\subsubsection{Status}

The Rapport de jury of the CAPES reminds candidates of the need to remain in control of their emotions despite the stress that they will almost inevitably feel. In order to raise students' awareness of this difficulty, I introduce the notion of status as described by Keith Johnstone in Improvisation and the Theatre (1979, pp. 33-74). Status is a term used widely in the theatre world to refer to the underlying dynamics occurring between characters on stage, but it is of direct relevance to students preparing to perform in front of a jury.

Status is rooted in behaviour, both verbal and non-verbal; it is "something one does" (Johnstone, 1979, p. 36). The following definition, which is proposed to their students by improvisation teachers Tom Salinski and Deborah Frances-White, provides a good starting point for using status in the MEEF 1 oral class:

In different circumstances or at different times, you will feel more or less powerful, more or less confident, more or less in control. But ultimately how you feel is private knowledge. Only you can know for certain how powerful or confident you're feeling. But it's also true that we make guesses all the time about how other people might be feeling, and those guesses are often right (just not 100 percent of the time). Status can be thought of as anything you would use to base such a guess on. (Salinski \& Frances-White, 2013, p. 91) 
Salinski and Frances-White (2013, pp. 90-1) provide a useful checklist of high and low status behaviours. According to these authors, high status behaviours may include holding eye contact, using infrequent gestures and speaking in short sentences, while low status behaviours may include answering quickly, saying "er" and touching your face.

Keith Johnstone (1979) makes the observation that many of his acting students are naturally "low status players" or "high status players" (pp. 35-6). Bearing this in mind, in the MEEF 1 class I begin by doing some practical observation exercises on status before getting them to practice playing both their preferred and least preferred status in various game formats (see Johnston, 1979, pp. 41-52; Salinski \& FrancesWhite, 2013, pp. 88-108 for examples). This helps students to become aware of their preferred status game and of how they tend to behave when speaking in front of the group, and is of direct relevance to training for an exam such as the CAPES oral. Indeed, in written feedback, which they are asked to provide in the form of a learning $\log ,{ }^{1}$ students often remark on the usefulness of this particular aspect of the course. The extracts below are typical and have been reproduced from student learning logs:

The activity to be more aware of the importance of our status was considerable. It was significant because we have to know the importance of our behaviour in front of a public. If we are teachers we have to take on a certain status to be credible and interesting. (Student A, 2013)

I have particularly enjoyed the first exercise we did when we had to judge each other's confidence by rating us from one to ten and also when people have to produce spontaneous speeches. Thus, I improved my confidence and my oral comprehension by listening very carefully, which I think are two important points for our future career as teachers. (Student B, 2013)

\subsubsection{Speaking spontaneously and holding the floor}

When giving a presentation, many students find it difficult to speak for the allocated amount of time before running out of things to say. This often happens when they are speaking from notes and fail to develop

1. Students were required to keep written logs in 2012 and 2013. As an experiment, this requirement was replaced by regular informal oral feedback sessions in 2014. I am considering re-introducing some form of written log in 2015. 
each point of their talk. The exercises described here are designed to help students overcome the problem of being over-reliant on notes. Before asking the students to deliver prepared, academic presentations during the final weeks of the semester, I work on giving them practice speaking spontaneously for several minutes at a time in the context of games and activities. One such activity involves a visualisation exercise and is based on an activity used by acting teachers. The other is a variation of the Yes, and improvisation game (Salinski \& Frances-White, 2013, pp. 59-62).

\subsubsection{The visualisation activity}

To begin the visualisation activity the teacher tells the students to find an isolated space in the room where they can sit comfortably. The teacher then invites the students to close their eyes and to imagine they are sitting at home in their room, the room in which they usually work. The students are told to remain silent throughout the visualisation. The teacher leads the students through the visualisation in detail with phrases such as:

Look at the wall in front of you. Perhaps it is painted, perhaps it has wallpaper? Notice what is on the wall. Are there any pictures or posters hanging from it? Are there any shelves? Is there a window in this wall? If so, is the blind open? What can you see when you look out of the window? Now focus on the wall to your left...

The teacher continues to lead the class through the visualisation, including details of the furniture in the room, the flooring, the ceiling, etc. Once the students have been led through this process, the teacher tells them to imagine one change to their room. This can be any physical detail - the colour of the wall, the view from the window, the furniture, etc. The important thing is that the students must visualise this change. Now the students are invited to take one more look around the room in its new guise. Finally, they are asked to open their eyes when they are ready. In groups of three or four, the students now take turns to describe their room (including the imaginary new detail) to each other. The job of the listeners is to try to identify the imaginary detail. Once this has been done, students come to the front of the room and describe their room to the whole class. As before, the job of the listeners is to identify the imaginary detail.

This activity is extremely engaging for both speakers and listeners and the visualisation process often makes impossible for the listeners to correctly identify the imaginary detail. The point of the exercise is 
of course to give students confidence in their ability to hold the floor and convince an audience. The comments of the audience also help, as students will try to identify some physical give-away of the "lie". Once this activity has been done, students tend to be more engaged when other more traditional class activities such as debates are introduced later in the semester.

\subsubsection{The Yes, and game}

In order to improve students' ability to hold the floor and to speak more fluently, I used a variation of the improvisation game Yes, and (Salinski \& Frances-White, 2013, pp. 54-63). Traditionally, this game is used to help improvising actors create two-person scenes by encouraging them to accept and build on each other's offers. A recurrent problem in improvisational theatre is that actors may often reject their stage partner's ideas and try to impose what they consider to be a better one. If an actor walks on to the stage and says, "Let's go to the zoo", his stage partner may judge this to be a boring idea, reject it and make a counter offer such as "No, let's go to the cinema". This can very quickly lead to an argument between the improvisers, slowing down the scene and stopping it from developing while they struggle to find out what it is about. Are they going to the zoo or the cinema?

By imposing the response "Yes, and" to any offer made by their stage partner, improvisation teachers have two aims. The first is to help actors work together by accepting each other's ideas with a "yes" instead of a "no". The second is to help them develop the scene by building on their partner's offer with an "and".

The Yes, and game can be adapted to help a student who is struggling to find anything interesting to say and/or who lacks confidence. The following example shows how it works.

After the Christmas break, students were asked to tell the rest of the group what they did over the holiday. While some students had no difficulty engaging with the audience and speaking for several minutes on this topic, one student in particular felt she had done nothing interesting and limited her contribution to a couple of sentences along the lines of: "I went to visit my family and we ate too much and drank too much. And on New Year's Eve I went to a party with my friends." I used the Yes, and game here to show the student how they might build on any aspect of their original statement. For example:

Student: I went back home to visit my family

Me: Yes, and 
Student: They live in a little village in Alsace

Me: Yes, and

Student: I hadn't been home since the summer

Me: Yes, and

Student: My parents were very happy to see me

Me: Now "yes, and" yourself!

Student: I helped them prepare the meal for Christmas Eve (yes, and) we had an unusual meal (yes, and) it was the first time I had eaten Kangaroo meat $[\ldots]$.

The point is that by prompting with "yes, and", students invariably discover more (relevant) things to talk about. It encourages them to listen to themselves, not over-plan and to realize that they are not expected to know exactly word for word what they are going to say before they start their talk. Moreover, in the CAPES exam itself they need to show that they are capable of presenting their work to the jury in a way that is "dynamique, spontanée et efficace" (Ministère de l'Éducation nationale, 2014b, p. 77). Indeed, I would further argue that this is a skill which is particularly important in the context of the postpresentation interview of the CAPES.

\section{Impact of the drama activities on student performance and evaluation}

As part of their evaluation for the course, the students were required to give a 15-minute presentation to the rest of the group, followed by a 10-minute question and answer session. This activity was scheduled for the final few weeks of the semester and by the time the students came to do it they had had a considerable amount of practice of talking in front of the group in a variety of formats (monologues, debates, discussions). While it was stipulated that the topic of the presentation had to be academic and linked to their MEEF studies, students were not expected to come up with a whole new topic for this class, but were encouraged to re-cycle material. This was because the course was focussed on working on their public speaking skills rather than on the content of their talk.

The presentations were explicitly linked to all the drama-based work we had done earlier in the semester by making sure students were aware of the performance skills they were expected to have acquired. Thus, 
before each presentation, a short sequence of five to ten minutes was dedicated to sharing performance advice among the class. Standing in a circle, each student would give one piece of advice to the speakers (e.g.: "don't forget to articulate", "make sure you look at the audience", "don't forget to breathe", "speak slowly", "don't play with your pen", etc.). As a result, it was extremely rare for students not to do a good job at this point.

The written feedback provided by students in their learning logs indicates that the course was generally well-received. Students were generally very happy with the content of the class, finding it both enjoyable and useful in terms of increasing their self-confidence in their ability to speak in public:

I appreciated the structure of the class, for on the one hand it helped me progressively to get rid of my timidity and, on the other hand, as this class is entertaining. (Student C, 2013)

$[\ldots]$ one of the things I had the chance to learn is speaking in front of an audience, because as we do it every week, it became usual. (Student D, 2013)

I have particularly enjoyed $[\ldots]$ when people have to produce spontaneous speeches. [...] I improved my confidence. (Student E, 2013)

Students also remarked favourably on the general approach of the course, and thought that it helped them feel comfortable exchanging opinions with fellow class-members. Some commented that they were able to apply what they had learned to other classes:

I could express my feelings to the audience or share my own experiences in English. In the same line, I am now able to improvise a story and I am less stressed out in front of an audience which is important as I would like to become a teacher. Consequently, I tried to use this confidence during an oral presentation in a British civilisation class $[\ldots]$ and the result was positive. (Student C, 2013)

\section{Discussion}

The objective of this paper was to show specifically how to link drama activities to the demands of the CAPES jury in terms of the quality of oral expression and to evaluate to what extent various exercises gleaned from drama training might be used to improve students' abilities in this area. 
One area on which the drama approach had a positive impact was on students' self-confidence. It is commonly accepted in the French context that students are generally reluctant to speak in class, and from comments made by my students during the course, it seems clear that even those training to be teachers are no exception. A large proportion of the students said they had been anxious throughout their studies about being judged negatively in class for the quality of their spoken English and so often preferred to say the minimum required to answer a teacher's question.

The experience of developing the course over a three-year period confirmed the importance of the need to make clear to the students from the outset exactly what is expected of them in terms of participation, and to introduce the drama-based activities gradually and non-threateningly. In order to counter the objections that some of them may have to the type of approach described here, it is also extremely important to link each activity to a specific requirement of the CAPES.

One potential obstacle to introducing drama techniques concerns the ambiguity of the role of the teacher in such a class. In many ways the function of the teacher in a drama-based oral English class as described here is akin to that of a workshop leader. However, while a workshop leader does not usually have to grade their students, this is not true of a university teacher, who must evaluate their students and give them a grade out of twenty for the quality of their oral English. The solution adopted in the course described here was to maintain a traditional language evaluation approach alongside a grade for active participation in the drama activities. Although the traditional exposé was a major component of the grade (50 percent), with marks awarded for structure, pronunciation, fluency, and grammatical and lexical accuracy, this was very much viewed as the final product of the process, i.e. of the ongoing work done in class each week. Students were therefore also graded on the basis of their participation and engagement with the activities rather than simply on the linguistic quality of their oral production. In order to maintain motivation, I felt it to be important that students feel free to engage with the activities without having to worry about being penalized for linguistic errors at each stage. This is not to say that any errors were not pointed out to them, indeed as the course progressed, general linguistic feedback was provided at the beginning of each session, based on any problems I had noted during the previous week.

A final consideration which needs to be addressed is the question of how much drama training the teacher needs in order to run the type 
of class described here. My own personal experience leads me to the conclusion that a certain basic level of training is necessary. Indeed, it is a daunting prospect to lead some of the activities described above without having at least experienced them first-hand as a participant in a workshop. One possible solution would be to hire a drama practitioner to co-teach the class, but this is not always possible. I can but agree with the view expressed by Via over three decades ago, "that it would make a great deal of sense for all teachers - no matter what discipline they are in - to have a suitable course in drama" (Via, 1980, p. 210).

\section{BIBLIOGRAPHY}

Aden, Joëlle. (2008). Compétences interculturelles en didactique des langues. Développer l'empathie par la théâtralisation. In J. Aden (ed.), Apprentissage des langues et pratiques artistiques (pp. 67-101). Paris: Manuscrit Université.

Algarra Carrasco, Victoria \& DiNapoli, Russell. (2012). Engaging in Dramatic Activities in English as a Foreign Language Classes at the University Level. Encuentro, 21, 94-103.

Beaven, Ana and Alvarez, Inma. (2014). Non-Formal Drama Training for In-service Language Teachers. Scenario: Journal for Drama and Theatre in Foreign and Second Language, 8, 5-18.

Belliveau, George \& Won, Kim. (2013). Drama in L2 Learning: A Research Synthesis. Scenario: Journal for Drama and Theatre in Foreign and Second Language, 2, 6-26.

Cornaz, Sandra \& Fonio, Filippo. (2014). Présentation et premiers résultats de la conception d'un référentiel de compétences en pratiques artistiques et apprentissage des langues. Dans J. Aden \& A. Arleo (eds), Actes du colloque "Langues en mouvement: didactique des langues et pratiques artistiques» (E-Crini, no. 6). Nantes: Éditions du CRINI. Retrieved from <http://www.crini.univ-nantes.fr/1402999033114/0/ fiche___pagelibre/\&RH=1367244575073\&RF=1402999468883> (accessed 23 February 2015).

Council of Europe. (2011). Common European Framework of Reference for Languages: Learning, Teaching, Assessment. Strasbourg: Council of Europe. Retrieved from <http://www.coe.int/t/dg4/linguistic/Source/ Framework_EN.pdf $>$ (accessed 25 February 2015).

Cusset, Yves. (2013). Se déformer pour mieux se former : d'un certain usage de la pratique du théâtre dans la formation des enseignants. Le français aujourd'hui, 1(180), 137-48. Retrieved from <http://dx.doi. org/10.3917/1fa.180.0137>. 
Dicks, Joseph E. \& Le Blanc, Barbara. (2009). Using Drama for Learning to Foster Positive Attitudes and Increase Motivation: Global Simulation in French Second Language Classes. Journal for Learning through the Arts, 5(1). Retrieved from <https://escholarship.org/uc/item/31745098> (accessed 24 February 2015).

DiNApoli, Russel. (2003). Towards Natural Engagement in Nonexhibitional Dramatic Role-Plays. Ibérica, 6, 15-38.

DiNAPoli, Russel. (2009). Using Dramatic Role-Play to Develop Emotional Aptitude. International Journal of English Studies, 9(2), 97-110. Retrieved from <http://dialnet.unirioja.es/servlet/articulo?codigo $=31042$ 63> (accessed 24 February 2015).

Fonio, Filippo \& Genicot, Geneviève. (2011). The Compatibility of Drama Language Teaching and CEFR Objectives - Observations on a Rationale for an Artistic Approach to Foreign Language Teaching at an Academic Level. Scenario: Journal for Drama and Theatre in Foreign and Second Language, 5(2), 75-89.

FunG, K. W. \& 馮健慧. (2005). A Study of the Effect of Anxiety in a Dramaoriented Second Language Classroom. MA Dissertation. Pokfulam, Hong Kong: The University of Hong Kong. Retrieved from < http://hub. hku.hk/handle/10722/40294> (accessed 23 February 2015).

Hardison, Debra M. \& Sonchaeng, Chayawan. (2005). Theatre Voice Training and Technology in Teaching Oral Skills: Integrating the Components of a Speech Event. System, 33(4), 593-608. Retrieved from <http:// dx.doi.org/10.1016/j.system.2005.02.001>.

Johnston, Chris. (2010). Drama Games for Those Who Like to Say No. London: Nick Hern Books.

Johnstone, Keith. (1979). Impro: Improvisation and the Theatre. London: Faber and Faber.

McCAllion, Michael. (1998). The Voice Book: Revised Edition. London: Faber and Faber.

Maley, Alan \& Duff, Alan. (1978). Drama Techniques in Language Learning. Cambridge: Cambridge University Press.

Maley, Alan \& Duff, Alan. (2005). Drama Techniques. A Resource Book of Communication Activities for Language Learners (3rd ed.). Cambridge: Cambridge University Press.

Ministère de l'Éducation nationale. (2012a). Données statistiques des concours du Capes de la session 2012. Retrieved from <http://www. education.gouv.fr/cid60943/donnees-statistiques-capes-session-2012. html> (accessed 1 May 2015).

Ministère de L'ÉducATiOn nATIONALE. (2012b). Rapport de jury CAPES externe Anglais. Session 2012. 
Ministère de L'Éducation nationale. (2013a). Données statistiques des concours du Capes de la session 2013. Retrieved from <http://www. education.gouv.fr/cid73088/donnees-statistiques-des-concours-capessession-2013.html> (accessed 1 May 2015).

Ministère DE L'ÉducATion nATIONALE. (2013b). Rapport de jury CAPES externe Anglais. Retrieved from <http://cache.media.education.gouv.fr/ file/capes_ext/00/0/anglais_270000.pdf $>$ (accessed 2 May 2015).

Ministère de L'Éducation nationale. (2014a). Données statistiques des concours du Capes de la session 2014. Retrieved from <http://www. education.gouv.fr/cid79809/donnees-statistiques-des-concours-capessession-2014.html> (accessed 1 May 2015).

Ministère DE L'ÉducATion nationale. (2014b). Rapport de jury CAPES externe Anglais. Retrieved from <http://cache.media.education.gouv.fr/ file/capes_ext/57/0/anglais_353570.pdf $>$ (accessed 2 May 2015).

RoyKA, Judith Gray. (2002). Overcoming the Fear of Using Drama in English Language Teaching. The Internet TESL Journal, 8(6). Retrieved from <http://iteslj.org/Articles/Royka-Drama.html>.

Salinsky, Tom \& Frances-White, Deborah. (2013). The Improv Handbook: The Ultimate Guide to Improvising in Comedy, Theatre, and Beyond. London: Bloomsbury.

Spolin, Viola. (1999). Improvisation for the Theater: A Handbook of Teaching and Directing Techniques. Evanston, USA: Northwestern University Press.

Stern, Susan L. (1980). Drama in Second Language Learning from a Psycholinguistic Perspective. Language Learning, 30(1), 77-100.

VIA, Richard A. (1976). English in Three Acts. Honolulu: East-West Center University Press of Hawaii.

VIA, Richard A. (1981). Language Learning Via Drama. In J. C. Cameron, M. A. Clark \& J. Schachter (eds), Building Bridges: Research and practice in Teaching English as a Second Language. Selected Papers from the Fourteenth Annual Convention of Teachers of English to Speakers of Other Languages, San Francisco, California. Retrieved from <http:// files.eric.ed.gov/fulltext/ED208643.pdf\#page=210> (accessed 25 February 2015).

Wessels, Charlyn. (1987). Drama (Resource Books for Teachers). Oxford: Oxford University Press.

Wilson, Ken. (2008). Drama and Improvisation. Oxford: Oxford University Press. 